\title{
Considerations Regarding the Combat of Illegal Criminal Punishment of "Disagreeable" Magistrates by using an Instigator Agent
}

\author{
Bogdan David \\ “Dimitrie Cantemir" Christian University, Faculty of Juridical and Administrative Sciences, Bucharest, Romania, \\ asr.bogdan@yahoo.com
}

\begin{abstract}
The present study is proposing to draw the attention of the international public to the methods and customs used by Romanian criminal prosecution institutions against some Romanian magistrates that either refused to collaborate with secret services or did not answer to political commands and, as a result, some criminal prosecution institutions belonging to a so called anticorruption structure undertook against those magistrates the usage of instigator agents, informers, in order to convict and dispose those magistrates from the judicial structure. We will present in this study a national and also European law that prohibits the use of illegal criminal investigation tools in order to obtain altered and unrealistic information of people targeted by NAD with the use of instigator agents called denunciators, the latter being people convicted of criminal offenses for various crimes, in order to enable the individuals concerned to be victim of unjust repression.
\end{abstract}

KEYWORDS: anticorruption, criminal prosecution, magistrates, unjust repression, unlawfulness

\section{Introduction}

In the practice of many states, but especially in the practice of criminal investigation institutions specialized in Romanian anticorruption combat (DNA) in the last 10 years, we encounter situations in which the criminal investigation institutions assume an active role, an instigator in committing different types of offenses. This is most often the case when the criminal prosecutors (mostly by denunciation) are informed that a certain person or a certain group of people would practice activities that fall under the regulations of the Criminal Code of that state and, from that moment, instead of investigating passively the actions of these people, law enforcement officers instigate new offenses in order to attract the person to criminal liability and apply appropriate punishment.

Unfortunately, in Romanian national legislation, we do not find any stipulations on this matter and that is why such behavior is not convicted and there is no legal groundwork. At the same time, the European Convention on Human Rights and Fundamental Freedoms, according to its jurisprudence, (Cases of Ramanauskas v. Lithuania (paragraph 60) and Khudobin v. Russia (paragraphs 133-135)) prohibits the use of such practices and considers them illegal and condemns such conduct on the part of the High Contracting Parties. As an example, the Court held that "when an accused invokes that he was the victim of an instigator, it is the responsibility of the judicial authorities to examine the facts and take the necessary actions to find out the truth in order to determine whether an instigation actually took place, in which case they have to draw conclusions in accordance with the Convention" (ECHR, Ramanauskas versus Lithuania, 2008).

\section{National and European legislative issues about prohibiting the usage of illegal criminal investigation tools}

One of the main problems in such cases is the fact that the responsibilities of the criminal prosecutors are mainly in finding and sanctioning the criminal behavior. However, in the case of "instigators", the State assumes the task of initiating an offense in order to punish a person whom they have persuaded into committing it, a person that maybe would never commit such an offense if the law enforcement structures would not instigate it. At the same time, by instigating people into committing criminal offenses, the state creates the risk of harming the rights and freedoms of third parties or damaging them. 
However, it is against all legal regulations that the law enforcement authorities should instigate the commission of such offenses by affecting all the procedural actions. On this matter, the State is entitled only to investigate passively the criminal offences and to find all possible evidences, relevant to each case. Instigation appears when criminal investigation authorities involve agents that are not limited only to examining in a genuinely passive manner the unlawful activity, but they actually influence the person concerned in order to incite him/her into committing a crime that otherwise would have not been committed. Instigation is applied in order to make it possible to establish the offense, to obtain evidence and to hold accountable (CEDO 2004, Case Ramanauskas, Eurofinacom v. France).

Based on the jurisprudence of the European Court of Human Rights and on the grounds of the Romanian Criminal Procedure Code, article 101, there is "instigation" if the following conditions are simultaneously fulfilled:

1. The allegedly criminal situation tends to be proven by the request from a person who has the responsibility to discover the offense, or when there is a direct invitation to commit an offense from a denouncer or an anonymous witness.

2. The absence of any indication that the act would have been committed without this intervention.

The admission of evidences emerged from an instigation by the law enforcement authorities and the issuing of a sentence of conviction based only on these evidence constitutes a fundamental flaw in criminal proceedings that affected the pronounced ruling, which may be relied upon procedural stage in national proceedings and even to initiate an extraordinary appeal. As the law does not distinguish, it takes into account the incitement from criminal investigation authorities, state agents, but also from any private person - for example denouncer - in order to obtain evidence leading to the criminalization of the perpetrator.

At the same time, the incitement is defined in Romanian law as a form of constrain, which comes out from the marginal name of the Romanian Criminal Procedure Code, article 68 from 1969, "Prohibition of Constraining Means", a law that prohibits in paragraph (1) to obtain evidence by constraint in the forms provided there (by using violence, threats or other means of constraint, promises and incitement), and in paragraph (2) expressly refers to forcing into committing or proceeding an offense in order to obtain evidence, as well as the Romanian Criminal Procedure Code, article 101 stipulates.

The principle of fairly administrating the evidence shows that:

1. Violence, threats or other means of constraint, as well as promises or incitement, are stopped in order to obtain evidence;

2. No methods or techniques of listening that affect the person's ability to remember conscientiously and voluntarily relate to the facts which are the subject of the test may be used, the prohibition applies even if the person consulted gives his consent to the use of such methods or listening techniques;

3. Criminal law enforcement authorities or other persons working with them shall be prohibited from influencing a person to commit or continue to commit a criminal offense in order to obtain evidence".

The ECHR states without any doubt that the instigation used by state agents in order to commit a crime is a violation of art. $6 \S 1$ of the Convention (ICCJ, Criminal Section, 2015).

From the principle of the benefit of the doubt it follows that the interpretation of the evidence in criminal matters is related to the in dubio pro reo standard, which also implies the condition of confidence, of a certain conviction of guilt.

At the same time, fair administration of evidence as part of the right to a fair trial occupies a supremely place in a democratic society and cannot be sacrificed in favor of the efficiency of the fight against corruption. The specific features of probation in the field of corruption crimes require the analysis of: the flagrant / instigation, the statements of the denouncing witnesses, the recording and the interception of the conversations, the expertise. 


\section{Aspects of judicial practice}

First of all, we serve as an example the case of the judge, Gabriela Bârsan, magistrate of the HCCJ, against whom the prosecution was ordered by the anticorruption prosecutors and sued by them for corruption without evidence. We exemplify this case because Mrs. Gabriela Bârsan is the wife of a renowned university professor and judge of the ECHR at that time, Mr. Corneliu Bârsan. Fortunately, Judge Gabriela Bârsan has been acquitted by the judicial control court.

The situation was not the same for Mrs. Maria David, the judge of the HCCJ, who in February 2012 was also accused by the anticorruption prosecutors, also for corruption offenses allegedly committed in 2009, using a denouncer (a convicted criminal to prison sentence for tax evasion) and a denouncing witness (who was the driver and the friend of the denouncer) who illegally benefited from the filing of the case despite denouncing the alleged corruption of Judge Maria David after the prosecution criminal proceedings had already begun, which is contrary to the legal provisions. The Romanian legislator, observing the multitude of such practices of denunciations made against alleged acts committed many years ago, rightly amended the provisions of the Criminal Procedure Code by introducing a new paragraph 29 (the third paragraph which stipulates that the denunciation must be made within 6 months from the date of the perpetration of the deed stipulated by the criminal law regarding this situation) (Romanian Criminal Procedure Code of 1969 - Article 290 CCP).

During the criminal investigation initiated against Judge Maria David, the whistleblowers had the technique of audio-video recording given by anticorruption prosecutors (HCCJ, Penal section, File no 2216/1/2012), denouncers systematically trying to provoke e Judge Maria David to talk about alleged trafficking influences even by offering her money that Judge Maria David has constantly rejected (PHCCJ, File no 26/P/2012). It should be pointed out that the two denunciators aggressively insisted on such instigating meetings with Judge Maria David even when the judge's mother was seriously ill and hospitalized and who died in 5 days and even when the judge was dealing with her mother's funeral. However, the use of such methods to obtain evidence contradicts the regulations of Art. 68 in conjunction with Art. 101 from Criminal Procedure Code of 1969 (under which Judge Maria David was prosecuted and sentenced) and the regulations of Art. $6 \S 1$ of the Convention.

Although Judge Maria David was subjected to trial and convicted by a panel of unlawfully constituted judges (Ioana Bogdan, a former prosecutor and councilor to the chief prosecutor of the NAD) who did not have the decision from the Romanian President to be appointed as judge, as the law provides, Judge Maria David notified the ECHR where she claimed violation of Article 6 of the ECHR.

The Court informed Judge Maria David that her request for meets the procedural conditions and admissibility and passed the first Chamber of the Court, and would receive a solution. Judge Maria David invoked at the ECHR art. 6 of the Convention, deposing a video recording in which Mona Pivniceru, the ministry of justice at the time, invited to a top-rated television show, declared that Judge Maria David should be excluded from the magistracy, although Madam David's trial was still ongoing.

It is also a notorious fact that, at that time, ICCJ Chairman Livia Stanciu made television statements that judges of the Romanian Supreme Court of are working along with anticorruption prosecutors.

Under these circumstances, how can we talk about fair trials and equality of arms (as stipulated by art. 6 of the ECHR and the principles ruling the Romanian criminal trial) in the judiciary system in Romania, when prosecutors and judges are working together in the conviction of people that are subjects to criminal prosecution and ruling? How can a person that is subject of a trial benefit from a fair defense and the benefit of the doubt (as provided by Article 6 (2) of the ECHR) if the prosecutor and the judge are on the same side in a criminal trial? 


\section{Conclusions}

The methods that are commonly used by the Romanian anticorruption authorities have led to serious abuses, methods that caused indignation in most democratic countries. Samples from the time of the prosecution, including wiretaps, are then selectively leaked into the media in order to reinforce the impression of guilt. Politicians, and even judges, make negative comments about the behavior of the defendant in a way that suggests that the process itself will be a mere formality. After being already identified as a criminal, the defendant is transformed into an outcast in society. It is not enough to punish the alleged villain. The purpose of this circus is to attack and discredit their political affiliation, opinions and affairs and to ensure that if no conviction is given by the court, public protests will be made.

The main areas of concern include politicization of justice, secret agreements between prosecutors and the executive, undermining of the internal intelligence agency attacks on the independence of the judiciary and abuses in NAD-driven processes.

The relationship between judges and prosecutors is another area in which the separation of powers is undermined on a regular basis. The conviction rate in cases sued by NAD is $92 \%$. This can only be done if the balance of justice is tilted strongly. To this end, the NAD uses different intimidation tactics to ensure that judges cooperate in keeping the conviction rate as high as possible. One method of NAD is to open investigations against judges who decide to acquit the defendants. This creates a climate of fear that distorts the making of right decisions. Corruption in the judiciary system is undoubtedly a problem in Romania and the combat of it has become a higher priority for NAD in the past years. However, there are questions about its role as an inquiry authority in cases of judicial corruption, creating a conflict of interest. We agree with the eradication of corruption, but with the use of legal methods that follow national and European norms.

We criticize selective justice based on political or other interests. If the judiciary authorities do not apply legal methods of investigating and prosecuting offenses and all they want is to prosecute and condemn certain people, it would mean that there is no difference between those institutions that are empowered to provide security of the law and, consequently, to its citizens, and offenders using misleading and illegal methods to achieve their own criminal aspirations.

\section{References}

CEDO. 2004. Ramanauskas, Eurofinacom v. France. no 58753/00.

ECHR. 2008. Ramanauskas v. Lithuania ([GC], no. 74420/01, §§ 35-37.

HCCJ. 2012. Criminal Section, File no 2216/1/2012.

ICCJ. 2015. Criminal Section, Decision no 65A / 2015, http://www.scj.ro/.

PHCCJ. 2012. File no 26/P/2012.

Romanian Criminal Procedure Code of 1969. 